\title{
The effects of tending cuttings on yield and value changes in black locust (Robinia pseudoacacia L.) stands: a case study
}

\author{
Károly Rédei ${ }^{1}$ - János Rásó ${ }^{2}$ - Tamás Ábri² - Zsolt Keserü $^{2}$ \\ ${ }^{1}$ University of Debrecen Faculty of Agricultural and Food Sciences and Environmental Management, Debrecen \\ ${ }^{2}$ National Agricultural Research and Innovation Centre - Forest Research Institute, Department of Plantation Forestry, Püspökladány \\ redei.karoly@gmail.com
}

SUMMARY

\begin{abstract}
Thinning experiments in black locust (Robinia pseudoacacia L.) stands have been carried out for many years in Hungary, as this species has a great economic importance in the timber supply of the country. This paper evaluates the effects of tending cuttings in two aspects: the effect on yield and stand value. The case study has proved that in black locust stands tending cuttings can not increase the periodic total production but the stem-quality index can be increased by $12 \%$.
\end{abstract}

Keywords: black locust (Robinia pseudoacacia L.), tending cuttings, periodic total production, stand value

\section{INTRODUCTION}

Tending cuttings is the removal of a proportion of the trees in a stand. It is usually practiced in order to provide more growing space for the remaining trees, to increase the total yield of usable timber over the life of the stand, and to provide wood from tending cuttings. It affects the growth and yield of stands, their diameter distribution, quality and stability. In forestry practice, the effect of tending cuttings on the size of the average tree or future crop trees is more importance than its effect on stand growth and yield, particularly for species like black locust. It is also obvious that total production is only one of the factors which influence the stand value. The distribution of the volume in different size classes has often much greater importance because the size and number of stems influence the cost of harvesting and the markets to which the sortiments can be sold.

An additional reason for tending cutting is that it should be a central part of any mitigation strategy to reduce the impact of future changes in the climate. There are three main reasons for this: wood products from stands that are thinned and pruned are more likely to be used in long-term end - uses; tending cuttings help to maintain healthy, resilient forests that are able to sequestrate carbon from the atmosphere and store it as woody biomass; and material produced in tending cutting can be used as fuelwood, a source of renewable energy, to help reduce fossil emissions.

The question if forest growth or yield can be increased or decreased by tending cuttings has been addressed by studies for many years. This question can be answered by testing Wiedemann's hypotesis, which states that volume growth is constant among a wide range of stand densities (Wiedemann, 1943). This relationship varies among species, but also depends on stand age and site conditions (Assmann, 1961; Kuiper and Schoenmarkers, 1990; Pardé, 1965; Persson, 1986; Pretzsch, 2009), so it is necessary to quantify it for each forest species.

In Hungary most of the relevant publications declare that tending cuttings can not increase the total production of stands with different tree species but in many cases they can increase the value of the stands (Béky, 1983; Béky and Solymos, 1991; Halupa, 1987; Majer, 1969; Rédei and Meilby, 2009).

In the following a tending cutting experiment will be presented, namely the effects of tending cuttings on yield and value of black locust stands. The paper also verifies and confirms the above-mentioned statements in the case of black locust.

\section{MATERIALS AND METHODS}

The experiment was established at Nagykörös 111A forest subcompartment ( $472170 ;$ E 194815) (Figure $1)$. The site type was a free-draining humus sand soil in the forest-steppe climate zone (annual precipitation is less than $550 \mathrm{~mm}$ normally). The yield class of the particular black locust stand: IV (Rédei, 1984). Two tending cutting treatments were carried out at the age of 15 and 20 years. We used a one-factor experimental design with two tending cutting grades without replicates. The area of each plot was $2500 \mathrm{~m}^{2}$. Treatment 1 is the control plot with no tending cutting. In treatment 2, the usual density in the Hungarian black locust management (at age of 15, N=1730 stems ha ${ }^{-1}$ and at age of $20, \mathrm{~N}=1075$ stems ha $^{-1}$ ) was applied (EMI, 1984).

The following parameters were measured at the age of 15, 20, 25 and 30: stem number, diameter at breast height and tree height. The calculated parameters were the followings: basal area, stem volume, volume of dead trees, stand volume (living stock), total production, mean annual increment and stem-quality index (SQI). The stem volume was calculated using the volume function based on the volume table for black locust (Sopp and Kolozs, 2000):

$$
\mathrm{v}=\frac{d^{2} \cdot h^{p o+1}}{(h-1,3)^{p o} \cdot 10^{8}} \cdot\left(p_{1} \cdot d \cdot h+p_{2} \cdot d+p_{3} \cdot h+p_{4}\right)
$$

where $\mathrm{d}$ is the diameter at breast height $(\mathrm{cm}), \mathrm{h}$ is tree height $(\mathrm{m}), \mathrm{p}_{\mathrm{o}}=4, \mathrm{p}_{\mathrm{l}}=-0.6326, \mathrm{p}_{2}=20.23, \mathrm{p}_{3}=0.00$ and $\mathrm{p}_{4}=3034$. 


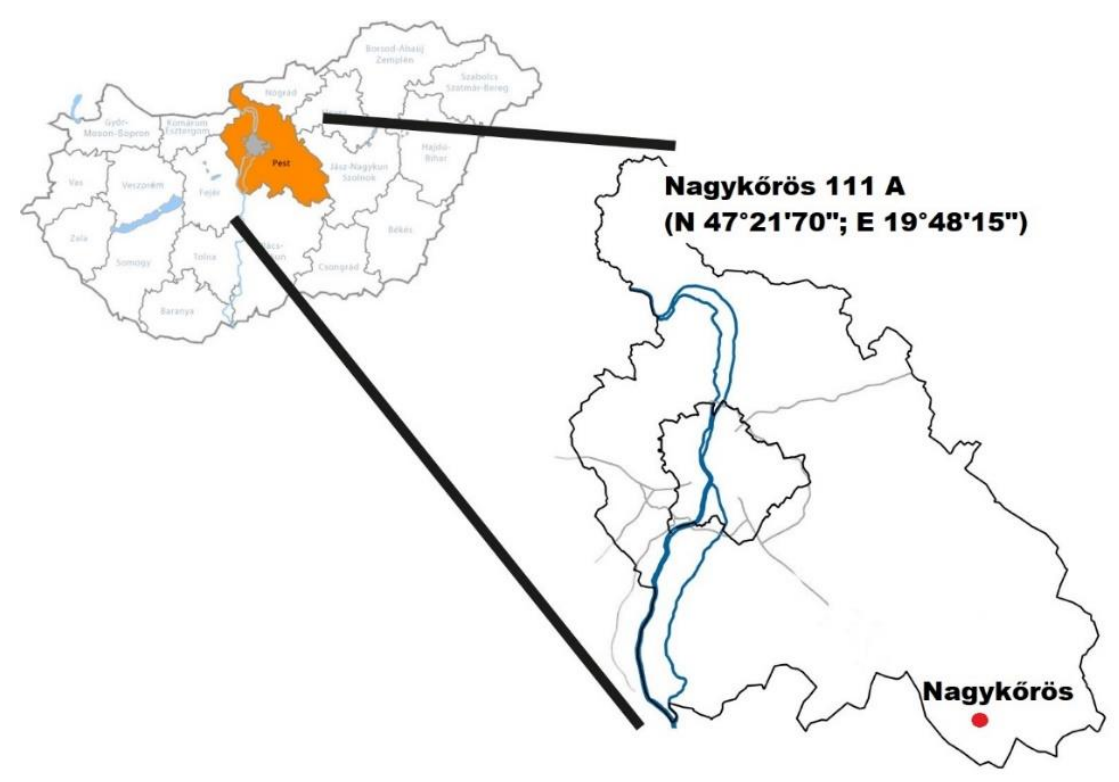

The living stock $(\mathrm{V})$ has been determined by means of a computer program developed by the Hungarian Forest Research Institute (HFRI) for calculating the wood volume; the volume of the average tree $\left(\mathrm{v}_{\mathrm{m}}\right)$ is computed according to the relation:

$\mathrm{V}_{\mathrm{m}}=\mathrm{VN}^{-1}$

where, $\mathrm{N}=$ number of stems per hectare.

The stem quality classes at the age of 36 are as follows (for calculating the stem-quality index):

- $\left(\mathrm{x}_{1}\right)$ Straight, cylindrical, healthy stems. Crooks are tolerated in one dimension only.

- $\left(\mathrm{x}_{2}\right)$ The stem is straight, forks are tolerated. Crooks are tolerated in one dimension only.

- $\left(\mathrm{x}_{3}\right)$ The stem is crooked and leaning. Minor crookedness in a second dimension is tolerated.

- $\left(\mathrm{x}_{4}\right)$ Very crooked in more than one dimension. Forked trees with stem defects.

The stem-quality index (SQI) was determined based on the following formula:

$$
S Q I=\frac{x_{1} n_{1}+x_{2} n_{2}+x_{3} n_{3}+x_{4} n_{4}}{n_{1}+n_{2}+n_{3}+n_{4}}
$$

where $x_{1}, x_{2}, x_{3}, x_{4}=$ tree quality classes, $n_{1}, n_{2}, n_{3}, n_{4}=$ tree numbers belonging to the single tree quality classes.

\section{RESULTS AND DISCUSSION}

Table 1 contains the most important yield and stemquality data. The table was compiled using data obtained from the stand surveys carried out between 15 and 30 years.
The following conclusions may be drawn from the data in the Table 1:

- Based on the black locust tending cutting experiment presented above no increase of the periodic total production increment due to the tending cuttings could be observed. The tending cuttings did not increase the amount of total production in absolute terms as compared to the control plot. The percentage relations of the initial volumes to the control plot before tending cutting are always higher than those after tending cuttings.

- According to the experiment tending cuttings had no effect on the periodic volume change. The periodic volume change ratio related to the control was dependent on the factors mentioned in the introduction. More investigations are needed to give a more precise description of the changes.

- The periodic total production increment values also clearly indicate that the tending cuttings do not have an increasing effect on the periodic increment of the total production. It is not very probable that the total production can significantly be increased (exceeding 5\%) with tending cuttings in any regime, intensity and frequency in the case of black locust managed with relatively low average rotation ages. This does not exclude different results with different species and circumstances.

- In black locust stands the quality of the stands can be improved with tending cuttings based on careful individual selection. In the studies presented the related stand quality indicator exceeded the indicator of the control stand by $12 \%$. Thus, the effect of the tending cuttings is manifested primarily in improving the quality of the stands and increasing their value. 


\begin{tabular}{|c|c|c|}
\hline \multirow[t]{2}{*}{ Factors } & \multicolumn{2}{|c|}{ Number of treatment } \\
\hline & I. (control) & II. \\
\hline 1. Initial wood stock before carrying out the tending cutting $\left(\mathrm{m}^{3} \mathrm{ha}^{-1}\right)$ & 87.2 & 92.4 \\
\hline - $\quad$ in percentage of the control $(\%)$ & 100.0 & 105.9 \\
\hline 2. Volume removed during the two tending cuttings $\left(\mathrm{m}^{3} \mathrm{ha}^{-1}\right)$ & 0.0 & 36.3 \\
\hline 3. Wood or living stock after the first tending cutting $\left(\mathrm{m}^{3} \mathrm{ha}^{-1}\right)$ & 87.2 & 80.5 \\
\hline \multicolumn{3}{|l|}{ 4. 15 years later (after carrying out the first tending cutting): } \\
\hline - living stock $\left(\mathrm{m}^{3} \mathrm{ha}^{-1}\right)$ & 124.4 & 112.4 \\
\hline - in percentage of the control $(\%)$ & 100.0 & 90.4 \\
\hline - mortality $\left(\mathrm{m}^{3} \mathrm{ha}^{-1}\right)$ & 33.9 & 15.3 \\
\hline - wood stock (living stock + mortality) $\left(\mathrm{m}^{3} \mathrm{ha}^{-1}\right)$ & 158.3 & 127.7 \\
\hline _ in percentage of the control $(\%)$ & 100.0 & 80.7 \\
\hline 5.Change in living stock 15 years later $\left(\mathrm{m}^{3} \mathrm{ha}^{-1}\right)$ & 37.2 & 31.9 \\
\hline - in percentage of the control $(\%)$ & 100.0 & 85.8 \\
\hline 6. Periodic total volume $\left(\mathrm{m}^{3} \mathrm{ha}^{-1}\right)$ & 158.3 & 164.0 \\
\hline - in percentage of the control $(\%)$ & 100.0 & 103.6 \\
\hline 7. Mean annual increment of the periodic total volume $\left(\mathrm{m}^{3} \mathrm{ha}^{-1} \mathrm{yr}^{-1}\right)$ & 4.7 & 4.8 \\
\hline - in percentage of the control $(\%)$ & 100.0 & 102.1 \\
\hline 8. Stem-quality index (SQI) at the age of 30 years & 2.94 & 2.60 \\
\hline$-\quad$ - in ratio of the control & 1.00 & 0.88 \\
\hline
\end{tabular}

\section{CONCLUSIONS}

Tending cuttings are silvicultural operations where the main objective is to reduce the density of trees in a stand, to improve the quality and growth of the remaining trees and to produce a marketable product.

Tending cuttings can also achieve other objectives such as changing the species composition of a stand, improving the health of the remaining trees or disturbing an established ground vegetation to enhance opportunities for natural regeneration.
The rate of tree growth in a stand depends on the species cultivated, the environmental circumstances of the site on which it is established and the applied silvicultural practices. Provided the site is fully occupied, with a reasonably intact canopy, where by trees can fully utilize the available resources, a stand will produce approximately the same amount of wood/yield at various stocking densities.

In this paper it was also verified, that in black locust stands the total production can not be increased by tending cuttings but the stand value can be improved by them.

\section{REFERENCES}

Assmann, E. (1961): Waldertragskunde. BLV Verlagsgesellschaft, München-Bonn-Wien.

Béky, A. (1983): A nevelővágás hatása a faegyedek vastagsági növekedésére kocsánytalan tölgyesekben. (The effect of tending cuts on the diameter increment in Quercus petraea stands). Erdészeti Kutatások 75:173-177. (in Hungarian).

Béky, A -Solymos, R. (1991): Egy kocsánytalan tölgy erdőnevelési kísérleti sor tanulságai. (Conclusions from a tending cutting experiment in Quercus petraea stand). Erdészeti Kutatások 82:227-235. (in Hungarian).

Erdőnevelési Műszaki Irányevek (EMI). (1984): (Tending Cut Guidelines). Agroinform Kiadó. (in Hungarian).

Halupa, L. (1987): A nyárnevelési kísérletek újabb eredményei. Erdészeti Kutatások 79:79-84. (Further results obtained from poplar tending cut experiments.) (in Hungarian).

Kuiper, C.-Schoenmakers, L. (1990): Evaluation of a ten years tending cutting experiment in Douglas fir. Forest components. Wageningen Agricultural University papers 6: 48-56.

Majer, A. (1969): A gyérítések racionalizálása. Rationalisation of tending cuttings. Az Erdő, XVIII. 9: 385-389. (in Hungarian).
Pardé, J. (1965): Intensité des éclaircies et production ligneuse. Revue Forestiéra Francaise, 936-945.

Persson, O. (1986): Tending cutting in Norway spruce in Sweden. Swedish University of Agricultural Sciences. Report, 18: 3-24.

Preitzsch, H. (2009): Forest Dynamics, Growth and Yield. Springer, Berlin.

Rédei, K. (1984): Akácosok fatermése. (Yield of black locust stands). FRI Report. (in Hungarian).

Rédei, K.-Meilby, H. (2009): Effect of Tending cutting on the Diameter Increment in Black Locust (Robinia pseudoacacia L.) Stands. Acta Silvatica et Lignaria Hungarica 5:63-74.

Sopp, L. - Kolozs, L. (2000): Fatömegszámítási táblázatok. (Volume tables). Mezőgazda Kiadó, Budapest. (in Hungarian).

Wiedemann, E. (1943): Der Vergleich der Massenleistung des Mischbestandes mit der Reinbestand. Allgemeine Forst- und Jagd- Zeitung 119: 123-132. 
